\title{
Follicular lymphoma
}

INSERM

\section{Source}

INSERM. (1999). Orphanet: an online rare disease and orphan drug data base. Follicular Iymphoma. ORPHA:545

Follicular lymphoma is a form of non-Hodgkin lymphoma (see this term) characterized by a proliferation of B cells whose nodular structure of follicular architecture is preserved. 